Supporting Information for the Environmental Science and Technology article:

\title{
Kinetics and Mechanistic Aspects of As(III) Oxidation by Aqueous Chlorine, Chloramines, and Ozone: Relevance to Drinking Water Treatment
}

Prepared on March 7, 2006

\author{
Michael C. Dodd, ${ }^{\dagger}$ Ngoc Duy Vu, ${ }^{\ddagger}$ Adrian Ammann, ${ }^{\dagger}$ Van Chieu Le, ${ }^{\ddagger}$ Reinhard Kissner, ${ }^{\S}$ Hung Viet \\ Pham, ${ }^{\ddagger}$ The Ha Cao, ${ }^{\ddagger}$ Michael Berg, ${ }^{\dagger}$ Urs von Gunten ${ }^{*}{ }^{\dagger}$ \\ ${ }^{\dagger}$ Swiss Federal Institute of Aquatic Science and Technology (EAWAG), CH-8600 Duebendorf, \\ Switzerland \\ ${ }^{\ddagger}$ Center for Environmental Technology and Sustainable Development (CETASD), Hanoi University of \\ Science, Nguyen Trai Street 334, Hanoi, Vietnam \\ ${ }^{\S}$ Laboratory of Inorganic Chemistry, ETH Zurich, 8093 Zurich, Switzerland \\ *Corresponding author phone: +41 4482352 70; fax: +41 448235210 \\ Author e-mail addresses: michael.dodd@eawag.ch, cetasd@hn.vnn.vn, ammann@eawag.ch, \\ kissner@inorg.chem.ethz.ch, michael.berg@eawag.ch, vongunten@eawag.ch
}

Text S1. Analytical methods

Text S2. Rate constant measurements

Text S3. Measurements of $\mathrm{O}_{3}$-As(III) stoichiometry with $\mathrm{O}_{3}$ in excess

Text S4. Real water sample procurement and composition

Text S5. Monitoring reactions in real waters

Text S6. Modeling As(III) loss by second-order kinetics in $\mathrm{NH}_{3}$-dominated systems

Text S7. Contribution of $\bullet \mathrm{OH}$ to observed As(III) losses during real water ozonation experiments

Figure S1. Reaction orders with respect to $\mathrm{As}(\mathrm{III})$ in the reactions between $\mathrm{As}(\mathrm{III})$ and $\mathrm{FAC}, \mathrm{NH}_{2} \mathrm{Cl}$, $\mathrm{NHCl}_{2}$, and $\mathrm{O}_{3}$

Figure S2. Temperature-dependence of apparent, second-order rate constant for decay of $\mathrm{NH}_{2} \mathrm{Cl}$ in the presence of excess As(III)

Figure S3. pH-dependence of observed pseudo-first order rate constants for decay of $\mathrm{NHCl}_{2}$ in the presence of excess As(III)

Figure S4. Observed stoichiometries for the reactions of As(III) with FAC, $\mathrm{NH}_{2} \mathrm{Cl}$, and $\mathrm{O}_{3}$ 
Text S1. Analytical methods

Ion Chromatography/ICP-MS method. Samples were diluted (generally 10-20 times) in $2 \mu \mathrm{M}$

phosphate solution prior to injection, and introduced to the column by automated injection-loop filling (20 $\mu \mathrm{L}$ ) via an auto-sampler module (ASX-510, CETAC). A micro-bore gradient pump 40 (Dionex) was used to deliver samples through the anion-exchange column (AG11/AS11, $250 \times 2 \mathrm{~mm}$, Dionex). Arsenic species were eluted $(0.3 \mathrm{~mL} / \mathrm{min})$ by a $\mathrm{NH}_{4} \mathrm{NO}_{3}$-gradient $(5 \mathrm{mM}$ at $0 \mathrm{~min}$ to $72 \mathrm{mM}$ at $4 \mathrm{~min}, 72 \mathrm{mM}$ from 4-7 $\mathrm{min}$ and equilibration at $5 \mathrm{mM}$ from 7-10.5 $\mathrm{min}$ ) at $\mathrm{pH}=7.0-7.3$. The effluent of the anionexchange column was connected to a micro-flow PFA nebulizer (ESI, Elemental Scientific Instrumentation) mounted on a cooled $\left(5^{\circ} \mathrm{C}\right)$ Scott-type quartz spray chamber of an Element2 (Thermo Electron) high-resolution, double-focusing, sector-field ICP-MS. Arsenic in the ion-exchange column effluent was tracked in low resolution at m/z 75. Plasma conditions were: power forward $1150 \mathrm{~W}$ (3 W reflected), argon gas flows $15.5 \mathrm{~L} / \mathrm{min}$ cooling, $0.9 \mathrm{~L} / \mathrm{min}$ plasma and $0.9 \mathrm{~L} / \mathrm{min}$ sample. MS chromatograms were exported from MS software in ASCII format and peak areas were integrated in Excel. Method detection and quantification limits were $0.4 \mu \mathrm{g} / \mathrm{L}$ As $\left(5.3 \times 10^{-9} \mathrm{M}\right)$ and $1.4 \mu \mathrm{g} / \mathrm{L} \mathrm{As}(1.9 \times$ $\left.10^{-8} \mathrm{M}\right)$, respectively. Relative standard deviations for each measurement ranged from $\pm 2-3 \%$.

Preservation of As(III)-As(V) speciation. Samples intended for measurement of As(III) and As(V) content within one day of preparation were stored at $4{ }^{\circ} \mathrm{C}$, without additional preservation, until analysis by IC/ICP-MS. Stability of arsenic speciation in the Phap Van water (described below) - spiked with equal concentrations of $\mathrm{As}(\mathrm{III})$ and $\mathrm{As}(\mathrm{V})$ ranging from $0.5-50 \mu \mathrm{g} / \mathrm{L}\left(6.7 \times 10^{-9}-6.7 \times 10^{-7} \mathrm{M}\right)$ - was found to be stable for up to 7 days of storage under such conditions. Additional controls indicated that As(III) was stable for at least two days in all other samples kept under such storage conditions.

In cases for which prolonged sample storage was necessary, an aluminosilicate adsorbent (0.1-0.3 mm particle diameter) was used to selectively remove As(V) from samples. Additional details of the adsorbent characteristics are available in ref. (1). One-mL cartridges packed with $\sim 0.8 \mathrm{~g}$ of the adsorbent were used for $\mathrm{As}(\mathrm{V})$ removal. 2.5-mL water samples collected with a $10 \mathrm{~mL}$-syringe were filtered 
through these cartridges at a flow rate of $\sim 10 \mathrm{~mL} / \mathrm{min}$. Total arsenic content in the filtrate was taken to represent As(III) content in a given sample. Individual filter cartridges were only used for a single As(V) removal.

Recoveries of As(III) and breakthrough of As(V) during aluminosilicate filtration were evaluated in Milli-Q water and in the Phap Van groundwater described below. To evaluate As(III) recovery, these waters were each spiked with an As(III) concentration of $100 \mu \mathrm{g} / \mathrm{L}\left(1.3 \times 10^{-6} \mathrm{M}\right)$. The difference in measured As(III) concentrations between filtered and non-filtered samples was less than $5 \%$. To evaluate As(V) breakthrough under typical sampling conditions, a sample of Milli-Q water was spiked with 300 $\mu \mathrm{g} / \mathrm{L} \mathrm{As}(\mathrm{V})\left(4.0 \times 10^{-6} \mathrm{M}\right)$ and a sample of Phap Van water spiked with $100 \mu \mathrm{g} / \mathrm{L} \mathrm{As}(\mathrm{V})\left(1.3 \times 10^{-6} \mathrm{M}\right)$. Less than $1 \%$ of the starting $\mathrm{As}(\mathrm{V})$ concentrations passed through a 1-mL filter cartridge during filtration of a 5-mL sample. Adsorbent capacity was evaluated by repeatedly passing 5-mL volumes of Milli-Q water containing $250 \mu \mathrm{g} / \mathrm{L} \mathrm{As}(\mathrm{V})\left(3.3 \times 10^{-6} \mathrm{M}\right)$ through a single 1-mL filter cartridge. Negligible As(V) breakthrough was observed even after filtration of $110 \mathrm{~mL}$. All samples were filtered at $\mathrm{pH}$ values within the range recommended by the aluminosilicate provider (i.e., between $\mathrm{pH} 4$ and 9)

HPLC analyses. All p-chlorobenzoic acid (pCBA) and benzaldehyde analyses were performed on a Hewlett-Packard 1050 HPLC system equipped with a Supelco Discovery RP Amide C16 column (3 mm × $250 \mathrm{~mm}, 5 \mu \mathrm{m})$, and a single-wavelength UV detector $(\lambda=250 \mathrm{~nm})$. Isocratic separations were performed with 35\% acetonitrile and 65\% $0.05 \mathrm{M} \mathrm{H}_{3} \mathrm{PO}_{4}$ (adjusted to $\mathrm{pH} 2.2$ with $\mathrm{NaOH}$ ). Limits of quantification by this method were approximately $0.05 \mu \mathrm{M}$ for each analyte. Standard deviations for each measurement varied from $\pm 1-3 \%$.

Text S2. Rate constant measurements

Free available chlorine. FAC decay $\left([\mathrm{FAC}]_{0}=1.5-5 \times 10^{-6} \mathrm{M}\right)$ was monitored in the presence of 1520× molar excesses of As(III) $\left([\mathrm{As}(\mathrm{III})]=15-50 \times 10^{-6} \mathrm{M}\right)$ via a continuous-flow, quenched-reaction 
(CFL) apparatus described in detail previously (2). Solutions of As(III) and FAC were mixed through a tee at constant flow-rate, $\mathrm{Q}_{\text {reaction }}=\mathrm{Q}_{\mathrm{FAC}}+\mathrm{Q}_{\mathrm{As}(\mathrm{III})}$, in 1:1 proportion with a multi-position Harvard Apparatus 22 syringe pump. The effluent of this tee was directed through one of seven PTFE loops with volumes, $\mathrm{V}_{\text {loop }}$, ranging from 16.1-199.3 $\mu \mathrm{L}$ (inclusive of dead volume). The effluent end of each PTFE loop was directed into a second tee receiving a stream of quenching reagent (DPD sulfate) to stop the reaction between $\mathrm{As}(\mathrm{III})$ and FAC after reaction times corresponding to $\mathrm{V}_{\text {loop }} / \mathrm{Q}_{\text {reaction. }}$. Residual FAC concentrations were measured by monitoring DPD cation radical absorbance at $515 \mathrm{~nm}$ (3). Desired reaction $\mathrm{pH}$ was achieved by buffering FAC and As(III) solutions with $10 \mathrm{mM}$ acetate (pH 5), $10 \mathrm{mM}$ phosphate (pH 6-8.5), or $40 \mathrm{mM}$ borate (pH 9-11). FAC and As(III) solutions containing twice the desired reaction concentrations were mixed in 1:1 proportion to initiate the reaction, which was quenched after various reaction times (ranging from $\sim 30-1400 \mathrm{~ms}$ ) with a deoxygenated solution containing $3 \mathrm{mM}$ of DPD sulfate (buffered at $\mathrm{pH} 6.5$ with $0.1 \mathrm{M}$ phosphate). Experiments were performed in triplicate, at room-temperature $\left(23( \pm 2){ }^{\circ} \mathrm{C}\right)$. Pseudo-first-order rate constants, $k_{\text {obs }}^{\prime}$, were obtained from plots of $\ln ([\mathrm{FAC}])$ versus time. As(III) reaction order was determined at $\mathrm{pH}$ 6, by varying [As(III)] from 25-100 $\mu \mathrm{M}$. Additional details of FAC-As(III) rate constant determinations and the raw data from which these rate constants were calculated are included in the Supporting Information - Part B.

Calibrations of FAC measurement were performed by measuring the absorbance of the DPD cation radical generated from various known concentrations of FAC, and were found to be linear over the full range of FAC concentrations employed in these studies. DPD solutions (3 $\mathrm{mM})$ were prepared as described previously (2). Calibration of the CFL apparatus - by means of the reaction between $\mathrm{NH}_{3}$ and $\mathrm{HOCl}$ - yielded a calculated value of $k_{\mathrm{HOCl}, \mathrm{NH}_{3}}^{\prime \prime}=2.4 \times 10^{6} \mathrm{M}^{-1} \mathrm{~s}^{-1}$, compared to the most preciselydetermined literature value of $3.1 \times 10^{6} \mathrm{M}^{-1} \mathrm{~s}^{-1}$ (4).

Chloramines. Rate constants for reactions of $\mathrm{As}(\mathrm{III})$ with $\mathrm{NH}_{2} \mathrm{Cl}$ and $\mathrm{NHCl}_{2}$ were measured in batch, by monitoring $\mathrm{NH}_{2} \mathrm{Cl}$ or $\mathrm{NHCl}_{2}$ decay (via spectrophotometric analysis at $243 \mathrm{~nm}$ and $310 \mathrm{~nm}$, 
respectively) in the presence of $[\mathrm{As}(\mathrm{III})]>>$ [chloramine $]_{0}$ at $25( \pm 0.5){ }^{\circ} \mathrm{C}$. In $\mathrm{NH}_{2} \mathrm{Cl}$ experiments, 25-ml volumes of $5 \mathrm{mM}$ As(III), buffered with $50 \mathrm{mM}$ phosphate ( $\mathrm{pH} 6.5$ to 8.5) or borate ( $\mathrm{pH} 9$ to 11), were dosed under constant, rapid stirring with $0.2 \mathrm{mM}$ of $\mathrm{NH}_{2} \mathrm{Cl}$, to initiate the reaction. Samples were then taken every 3 min for $\mathrm{NH}_{2} \mathrm{Cl}$ analysis. Experiments were performed in triplicate at each $\mathrm{pH}$. Controls verified that $\mathrm{NH}_{2} \mathrm{Cl}$ losses in the absence of $\mathrm{As}(\mathrm{III})$ were negligible during each experiment.

In $\mathrm{NHCl}_{2}$ experiments, 6-mL volumes of $13 \mathrm{mM} \mathrm{As(III),} \mathrm{buffered} \mathrm{with} 60 \mathrm{mM}$ acetate (pH 4-5) were pipetted into each of two 2-cm spectrophotometer cells. These As(III) solutions were then dosed with 60 $\mathrm{mM}$ acetate solutions containing 350-550 $\mu \mathrm{M}$ of $\mathrm{NHCl}_{2}$, stoppered to prevent evaporative loss of $\mathrm{NHCl}_{2}$, and agitated by rotating the stoppered cell several times. Decay of $\mathrm{NHCl}_{2}$ in these duplicate cells was followed for 2 to $5 \mathrm{~h}$, depending on the $\mathrm{pH}$, by measurement at $310 \mathrm{~nm}$. Controls verified that $\mathrm{NHCl}_{2}$ was stable in the absence of As(III) during experiments conducted at $\mathrm{pH}$ 4-4.3. Non-negligible losses of $\mathrm{NHCl}_{2}$ were observed in As(III) controls at $\mathrm{pH} 4.5$ and 5. Measured rates of $\mathrm{NHCl}_{2}$ loss in the presence of As(III) at $\mathrm{pH} 4.5$ and 5 were corrected for $\mathrm{NH}_{2} \mathrm{Cl}$ loss rates observed in the corresponding As(III) controls.

$k_{o b s}^{\prime}$ values were obtained from plots of $\ln \left(\left[\mathrm{NH}_{2} \mathrm{Cl}\right]\right)$ and $\ln \left(\left[\mathrm{NHCl}_{2}\right]\right)$ versus time, respectively. As(III) reaction orders were determined in the case of $\mathrm{NH}_{2} \mathrm{Cl}$ by varying [As(III)] from 2-15 mM, at $\mathrm{pH}$ 8.5, and in the case of $\mathrm{NHCl}_{2}$ by varying [As(III)] from 5-40 mM, at $\mathrm{pH} 4$. Additional details of rate constant determinations for the $\mathrm{NH}_{2} \mathrm{Cl}$-As(III) and $\mathrm{NHCl}_{2}$-As(III) reactions, in addition to the raw data from which these rate constants were calculated, are included in the Supporting Information - Part B.

Ozone (continuous-Flow). Rate constants for the reaction between $\mathrm{O}_{3}$ and As(III) were measured using the same apparatus and procedures as for the FAC-As(III) reaction. $\mathrm{O}_{3}$ loss $\left(\left[\mathrm{O}_{3}\right]_{0}=1 \mu \mathrm{M}\right)$ was monitored in the presence of $10 \mu \mathrm{M}$ of $\mathrm{As}(\mathrm{III})$. The reaction between $\mathrm{As}(\mathrm{III})$ and $\mathrm{O}_{3}$ was quenched with a $4 \mu \mathrm{M}$ solution of indigo trisulfonate (which was adjusted to $\mathrm{pH} 2$ with $\mathrm{H}_{3} \mathrm{PO}_{4}$ to ensure 1:1 stoichiometry 
of the indigo- $\mathrm{O}_{3}$ reaction (5)), and $\mathrm{O}_{3}$ residual was followed by monitoring the quenched solution's absorbance at $600 \mathrm{~nm}(5)$.

Working $\mathrm{O}_{3}$ stocks were prepared in Milli-Q water adjusted to $\mathrm{pH} 4$ with sulfuric acid to stabilize $\mathrm{O}_{3}$ (6). These $\mathrm{O}_{3}$ stocks were stored in a stoppered 1-L flask connected to a Metrohm Dosimat dispensing system, prior to transfer from the Dosimat to a 25-mL, Hamilton gas-tight syringe for use in kinetics experiments. Working $\mathrm{O}_{3}$ stock concentrations were checked before each experiment by mixing a syringe-full of the $\mathrm{O}_{3}$ stock solution in 1:1 proportion with Milli-Q water (in place of As(III)). Constant solution pH was maintained by buffering As(III) solutions in phosphate buffers of approximately $10 \mathrm{mM}$ concentration. Separate experiments conducted by manually mixing equal volumes of $\mathrm{pH} 4$ water and each buffered solution indicated that $\mathrm{pH}$ of the mixed solutions did not change by more than 0.1 unit from that of the buffered As(III) stock. $10 \mathrm{mM} t-\mathrm{BuOH}$ was added as a hydroxyl radical $(\cdot \mathrm{OH})$ scavenger to each As(III) solution. However, this was later found to be unnecessary, because stoichiometric data and mechanistic findings obtained subsequent to CFL experiments indicated that the reaction of As(III) with $\mathrm{O}_{3}$ does not generate $\bullet \mathrm{OH}$ (see the Mechanistic Considerations section in the main text), and $\mathrm{As}(\mathrm{III})-\mathrm{O}_{3}$ reaction kinetics are fast enough to ensure that $\bullet \mathrm{OH}$ formation via autocatalytic $\mathrm{O}_{3}$ decomposition is negligible at the $\mathrm{pH}$ values used for these experiments. All experiments were performed at roomtemperature (i.e., $\left.23( \pm 2){ }^{\circ} \mathrm{C}\right) . k_{o b s}^{\prime}$ values were obtained from plots of $\ln \left(\left[\mathrm{O}_{3}\right]\right)$ versus time. Each $\left[\mathrm{O}_{3}\right]$ value used in these plots was obtained by averaging the $\left[\mathrm{O}_{3}\right]$ values measured for at least three individual samples collected at the corresponding reaction time during a single CFL experiment. Detailed examples of these calculations are provided with the corresponding raw experimental data in the Supporting Information - Part B. As(III) reaction order was determined by varying [As(III)] from 10-30 $\mu \mathrm{M}$, at pH 2.

Ozone (stopped-flow). Stopped-flow measurements of $\mathrm{O}_{3}$ decay in the presence of excess As(III) were performed using an Applied PhotoPhysics SX-17MV system, with temperature controlled at $20( \pm 0.5){ }^{\circ} \mathrm{C}$. As(III) and $\mathrm{O}_{3}$ solutions, at concentrations ranging from $[\mathrm{As}(\mathrm{III})]=40-200 \mu \mathrm{M}$, and $\left[\mathrm{O}_{3}\right]=$ 2-10 $\mu \mathrm{M}$, were buffered with either $10 \mathrm{mM}$ phosphate ( $\mathrm{pH} \mathrm{3}$, and 6-7.8) or acetate ( $\mathrm{pH} 4$ and 5). $\mathrm{O}_{3}$ 
solutions were prepared by transferring appropriate volumes of undiluted $\mathrm{O}_{3}$ stock (via gas-tight syringe) from a Dosimat to $10 \mathrm{mM}$ buffer solutions immediately prior to each experiment. Buffered $\mathrm{O}_{3}$ and $\mathrm{As}$ (III) solutions were then mixed at 1:1 proportion to initiate the reaction between $\mathrm{As}(\mathrm{III})$ and $\mathrm{O}_{3}$, and $\mathrm{O}_{3}$ loss was monitored directly at $\lambda=258 \mathrm{~nm}$. $k_{o b s}^{\prime}$ values were calculated by exponential regression (SigmaPlot 2002, SPSS Software) of the average $\mathrm{O}_{3}$ decay curves calculated from at least nine replicate curves for each $\mathrm{pH}$. Details of these calculations are included with the corresponding raw experimental data in the Supporting Information - Part B. $t$-BuOH was not added to solutions used in stopped-flow experiments, for reasons mentioned above. As(III) reaction order was investigated at at $\mathrm{pH} 3$ and 7, by varying [As(III)] from 100-500 $\mu \mathrm{M}$.

Text S3. Measurements of $\mathrm{O}_{3}-\mathrm{As}(\mathrm{III})$ stoichiometry with $\mathrm{O}_{3}$ in excess

Solutions of $\mathrm{As}(\mathrm{III})$ were prepared at 8-120 $\mu \mathrm{M}$ concentration in either $\mathrm{pH} 2$ water acidified with sulfuric acid or in $10 \mathrm{mM}$, pH 7 phosphate buffers. $\mathrm{O}_{3}$ was prepared at $200 \mu \mathrm{M}$ in Milli-Q water adjusted to $\mathrm{pH} 2$ (for experiments with $\mathrm{pH} 2 \mathrm{As}(\mathrm{III})$ solutions) or $\mathrm{pH} 4$ (for experiments with $\mathrm{pH} 7 \mathrm{As}(\mathrm{III}$ ) solutions) with sulfuric acid. Working $\mathrm{O}_{3}$ stocks were stored and transferred as in the reaction kinetics experiments conducted using the continuous-flow apparatus. After transfer of a working $\mathrm{O}_{3}$ stock into a Hamilton gas-tight syringe, initial $\mathrm{O}_{3}$ concentration in the syringe was checked by mixing in 1:1 proportion with $\mathrm{As}$ (III)-free water (for $\mathrm{pH} 2$ experiments) or $10 \mathrm{mM}, \mathrm{pH} 7$ phosphate buffer (for $\mathrm{pH} 7$ experiments) contained within an identical $25-\mathrm{mL}$ syringe. The two solutions were driven by a multiposition syringe pump (at a flow rate of $10 \mathrm{~mL} / \mathrm{min}$ ) through the inlet channels of a mixing tee whose outlet was directed through a 1-cm flow-through spectrophotometer cell. $\mathrm{O}_{3}$ concentrations were directly measured at $\lambda=258 \mathrm{~nm}$. The standardized $\mathrm{O}_{3}$ solution contained within the first syringe was then similarly mixed in 1:1 proportion with a solution of As(III) contained within a third syringe, and the residual $\mathrm{O}_{3}$ concentration was recorded after $5 \mathrm{~s}$ of reaction time ( $t_{0.999, \mathrm{As}(\mathrm{III})}$, or $t$ for $99.9 \%$ depletion of 
As(III), was $\sim 13$ and 5 ms under these conditions at $\mathrm{pH} 2$ and 7, respectively). This procedure was repeated in duplicate for each As(III) dose. Control experiments showed that $\mathrm{O}_{3}$ losses between each standardization step and $\mathrm{As}(\mathrm{III})-\mathrm{O}_{3}$ mixing step were negligible.

Text S4. Real water sample procurement and composition

Real water samples were collected from Lake Zurich, Switzerland, and from two partially-treated drinking waters derived from reduced groundwater sources in Hanoi, Vietnam to validate the applicability of reaction kinetics reported here to modeling reactions in real water systems. Lake Zurich samples were taken from a depth of $30 \mathrm{~m}$ below the surface of the lake, which represents the raw water for Zurich's drinking water supply. The Vietnamese water samples were taken from Hanoi's Phap Van and Yen Phu drinking water treatment facilities. Each water sample was filtered through a $0.45-\mu m$ membrane immediately after collection, protected from light, and transported to the laboratory (EAWAG) as rapidly as possible (typically 2-3 days transport time), whereupon it was refrigerated at $\sim 4{ }^{\circ} \mathrm{C}$ prior to usage.

The Phap Van and Yen Phu plants draw raw water from two separate groundwater supplies that contain relatively high total arsenic concentrations comprised predominantly of As(III), in addition to high Fe(II) concentrations, and - in the case of PV water - high $\mathrm{NH}_{3}$ concentrations (7). At each plant, the respective raw groundwater sources first undergo aeration to oxidize dissolved Fe(II), followed by a settling step to allow precipitation of Fe(III)-(hydr)oxides formed during oxidation of Fe(II). The aerated waters are then passed through a gravity-filter bed containing quartz-sand filter media, before chlorination and final passage into the city's distribution network. The Phap Van and Yen Phu samples were taken from locations in each plant between their filtration and final chlorination steps, at which point As(III) concentrations are very low. IC/ICP-MS analyses showed that native As(III) concentrations were $<2$ $\mu \mathrm{g} / \mathrm{L}$ in the Yen Phu and Phap Van water samples. Because these water samples were saturated with dissolved oxygen by the time they passed through the filter beds in the plants, and were subsequently 
filtered through $0.45-\mu \mathrm{m}$ membranes, Fe(total) concentrations in each were also negligible. Other important water quality parameters are provided in the main text (Table 2).

Separate volumes of Lake Zurich water were amended with a $\mathrm{NH}_{4} \mathrm{Cl}$ dose of either $1 \mathrm{mg}-\mathrm{N} / \mathrm{L}(7.1 \times$ $\left.10^{-5} \mathrm{M}\right)$ to yield LZ1 water, or $20 \mathrm{mg}-\mathrm{N} / \mathrm{L}\left(1.4 \times 10^{-3} \mathrm{M}\right)$ to yield LZ20 water, to provide synthetic waters for quantitatively assessing the affect of various $\mathrm{NH}_{3}$ concentrations on As(III) oxidation rates in a real water dosed with FAC. Native As(III) concentration is $<1 \mu \mathrm{g} / \mathrm{L}$ in Lake Zurich water.

Text S5. Monitoring reactions in real waters.

Batch chlorination experiments. Each real water was spiked with $50 \mu \mathrm{g} / \mathrm{L} \mathrm{As}(\mathrm{III})\left(6.7 \times 10^{-7} \mathrm{M}\right)$ and added in various volumes to either $30-\mathrm{mL}$ amber, borosilicate glass vials, or 100 -mL glass bottles wrapped in aluminum foil to exclude light, depending on the number of samples desired from each experiment. These solutions were thermostatted at $25( \pm 0.5){ }^{\circ} \mathrm{C}$ and, under constant, rapid stirring (via magnetic stir-bars), dosed with various concentrations of FAC. Samples were taken from all waters after $10 \mathrm{~s}$ of reaction time, quenched with $1 \mathrm{mM}$ ascorbic acid, filtered through aluminosilicate media to remove $\mathrm{As}(\mathrm{V})$, and subsequently analyzed by IC/ICP-MS for residual As(III). Additional samples were taken from LZ1, LZ20, and PV waters at 1- or 3-h intervals, up to $9 \mathrm{~h}$ reaction time, and analyzed in the same manner. In the latter two cases, reaction vials were capped after taking the 10-s samples to prevent unnecessary exposure to light. Samples collected at $10 \mathrm{~s}$ of reaction time were used to assess oxidation of As(III) by FAC. Subsequent samples were collected to monitor oxidation of residual As(III) in the presence of the excess $\mathrm{NH}_{2} \mathrm{Cl}$ formed by reaction of FAC with $\mathrm{NH}_{3}$ in the LZ1, LZ20, and PV waters. $\mathrm{NH}_{2} \mathrm{Cl}$ concentrations were monitored during each reaction by DPD-colorimetry (3).

Continuous-flow chlorination experiments. Oxidation of As(III) by FAC was directly monitored in real waters by means of the CFL apparatus described above, at room temperature (i.e., $\left.23( \pm 2){ }^{\circ} \mathrm{C}\right)$. The contents of two 25 -mL syringes - one containing the real water spiked with $100 \mu \mathrm{g} / \mathrm{L}\left(1.3 \times 10^{-6} \mathrm{M}\right)$ of As(III); the other containing $10 \mathrm{mM}$ phosphate buffer adjusted to the $\mathrm{pH}$ of the real water and spiked with 
the appropriate FAC concentration - were mixed in 1:1 proportion to initiate the reaction. FAC consumption by each real-water matrix was monitored by quenching FAC residuals with DPD. As(III) oxidation was monitored separately by quenching residual chlorine in the reaction solution with a $10-\mathrm{mM}$ ascorbic acid solution, to eliminate the possibility of side-reactions between the DPD cation radical and residual As(III) after sampling. As(III) samples were taken from the effluent leaving the CFL mixing valve, filtered through the aluminosilicate media to remove As(V), and analyzed by IC/ICP-MS.

Batch ozonation experiments. 20-mL volumes of each real water, spiked with $50 \mu \mathrm{g} / \mathrm{L}$ of As(III) (6.7 $\times 10^{-7} \mathrm{M}$ ), were added to 30 -mL, amber, borosilicate glass vials, and thermostatted at $20( \pm 0.5){ }^{\circ} \mathrm{C}$. Under constant, rapid stirring, these solutions were dosed with various concentrations of $\mathrm{O}_{3}$. Samples were taken from each water after 10-s reaction intervals, dosed with 1-mM 3-buten-2-ol to ensure quenching of any residual $\mathrm{O}_{3}$, filtered through aluminosilicate media to remove $\mathrm{As}(\mathrm{V})$, and subsequently analyzed by IC/ICP-MS.

Continuous-flow ozonation experiments. Oxidation of $\mathrm{As}(\mathrm{III})$ by aqueous $\mathrm{O}_{3}$ was monitored via CFL reaction monitoring (2), at room temperature (i.e., $23( \pm 2)^{\circ} \mathrm{C}$ ). Each real water solution was dosed with $100 \mu \mathrm{g} / \mathrm{L}$ As(III) $\left(1.3 \times 10^{-6} \mathrm{M}\right)$ and $2 \mu \mathrm{M}$ of $p$ CBA (used as a hydroxyl radical probe (8)), to yield reaction conditions of $50 \mu \mathrm{g} / \mathrm{L} \mathrm{As}(\mathrm{III})\left(6.7 \times 10^{-7} \mathrm{M}\right)$ and $1 \mu \mathrm{M}$ of $p$ CBA. Working $\mathrm{O}_{3}$ stocks were prepared in Milli-Q water adjusted to $\mathrm{pH} 4$ with sulfuric acid, and handled as in $\mathrm{As}(\mathrm{III})-\mathrm{O}_{3}$ reaction kinetics measurement experiments. Online pH-adjustment of the $\mathrm{O}_{3}$ working stocks was required to permit execution of experiments at each real water's native $\mathrm{pH}$, because $\mathrm{O}_{3}$ is quite unstable in aqueous solution at circumneutral and higher $\mathrm{pH}$ values (6). This was achieved by pumping the $\mathrm{O}_{3}$ working stock and a $10 \mathrm{mM}$ phosphate buffer of the same $\mathrm{pH}$ as the corresponding real water through a mixing tee in 1:1 proportion, and routing the effluent directly into one channel of a second mixing tee receiving a parallel stream of real water at a flow rate equal to that of the pre-mixed $\mathrm{O}_{3}$ stream. The effluent of the second mixing tee was directed through one of the CFL reaction loops described above. After passage of the reaction solution through a given reaction loop, residual $\mathrm{O}_{3}$ was quenched with a 1-mM solution of 
cinnamic acid, which reacts with $\mathrm{O}_{3}$ to yield benzaldehyde in 1:1 stoichiometry (with $k_{\text {app, } \mathrm{O}_{3}}^{\prime \prime} \sim 3.8 \times 10^{5}$ $\mathrm{M}^{-1} \mathrm{~s}^{-1}$ at circumneutral $\left.\mathrm{pH}(9)\right)$. Quenched samples were collected for analysis of As(III), benzaldehyde, and pCBA. Residual ozone concentrations and $\bullet \mathrm{OH}$ exposures were calculated from benzaldehyde and pCBA measurements, respectively (see Text S7 for additional discussion of $\bullet \mathrm{OH}$ exposure calculations). Initial $\mathrm{O}_{3}$ concentrations were measured by the same procedure, with Milli-Q water substituted for As(III)-amended real water.

Text S6. Modeling As(III) loss by second-order kinetics in $\mathrm{NH}_{3}$-dominated systems

In waters containing $\mathrm{NH}_{3}$ concentrations (in mg-N/L) at least 0.5 times greater than the concentration of DOC (in mg-C/L), FAC loss will most likely dominated by the $\mathrm{NH}_{3}-\mathrm{FAC}$ reaction. FAC loss can be modeled in such cases according to the second-order model represented by eq S1.

$[\mathrm{FAC}]=\frac{[\mathrm{FAC}]_{0}\left(1-\frac{\left[\mathrm{NH}_{3}\right]_{0}}{[\mathrm{FAC}]_{0}}\right)}{1-\frac{\left[\mathrm{NH}_{3}\right]_{0}}{[\mathrm{FAC}]_{0}} e^{\left(\left(\left[\mathrm{NH}_{3}\right]_{0}-[\mathrm{FAC}]_{0}\right) k_{a p p, \mathrm{FAC}, \mathrm{NH}_{3}} t\right)}}$

This can be incorporated into a rate expression for As(III) loss (eq S2),

$[\mathrm{As}(\mathrm{III})]=[\mathrm{As}(\mathrm{III})]_{0} e^{\left(-k_{a p p, \mathrm{FAC}}^{\prime \prime} \int_{0}^{t}[\mathrm{FAC}] d t\right)}$

to yield eq S3.

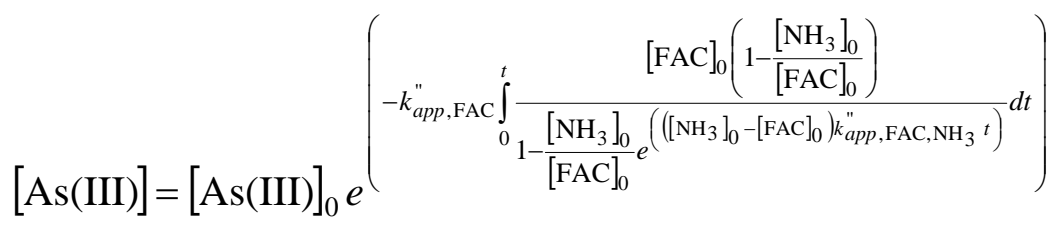

The integral in eq S3 can be represented by the general form shown in eq S4,

$\int_{0}^{t} \frac{a}{1-b e^{(c t)}} d t=\int_{0}^{t} \frac{-a}{b e^{(c t)}-1} d t=\int_{0}^{t}\left(\frac{a\left(b e^{(c t)}-1\right)}{b e^{(c t)}-1}-\frac{a b e^{(c t)}}{b e^{(c t)}-1}\right) d t=\int_{0}^{t} a\left(1-\frac{b e^{(c t)}}{b e^{(c t)}-1}\right) d t$ 
where $a=[\mathrm{FAC}]_{0}\left(1-\frac{\left[\mathrm{NH}_{3}\right]_{0}}{[\mathrm{FAC}]_{0}}\right), \quad b=\frac{\left[\mathrm{NH}_{3}\right]_{0}}{[\mathrm{FAC}]_{0}}$, and $c=\left(\left[\mathrm{NH}_{3}\right]_{0}-[\mathrm{FAC}]_{0}\right) k_{a p p, \mathrm{FAC}, \mathrm{NH}_{3}}^{\prime \prime}$ Eq S4 can be integrated with respect to $t$, to yield eq S5.

$$
\left|a t-\ln \left(b e^{(c t)}-1\right)\right|_{0}^{t}=\left|\frac{a}{c} \ln \left(e^{(c t)}\right)-\ln \left(b e^{(c t)}-1\right)\right|_{0}^{t}=\left|\frac{a}{c} \ln \left(\frac{e^{(c t)}}{b e^{(c t)}-1}\right)\right|_{0}^{t}=\frac{a}{c}\left(\ln \left(\frac{e^{(c t)}}{b e^{(c t)}-1}\right)-\ln \left(\frac{1}{b-1}\right)\right)
$$

Eq S5 can then be substituted with appropriate variables and incorporated into eq S3 to yield eq S6.

$$
[\mathrm{As}(\mathrm{III})]=[\mathrm{As}(\mathrm{III})]_{0} e^{\left(\frac{-k_{a p p, \mathrm{FAC}, \mathrm{As}(\mathrm{IIII})}^{\prime \prime}[\mathrm{FAC}]_{0}\left(1-\frac{\left[\mathrm{NH}_{3}\right]_{0}}{[\mathrm{FAC}]_{0}}\right)}{\left(\left[\mathrm{NH}_{3}\right]_{0}-[\mathrm{FAC}]_{0}\right) k_{a p p, \mathrm{FAC}, \mathrm{NH}_{3}}^{\prime \prime}}\left(\ln \left(\frac{e^{\left(\left(\left[\mathrm{NH}_{3}\right]_{0}-[\mathrm{FAC}]_{0}\right) k_{a p p, \mathrm{FAC}, \mathrm{NH}_{3} t}^{\prime \prime}\right.}}{\frac{\left[\mathrm{NH}_{3}\right]_{0}}{[\mathrm{FAC}]_{0}} e^{\left(\left(\left[\mathrm{NH}_{3}\right]_{0}-[\mathrm{FAC}]_{0}\right) k_{a p p, \mathrm{FAC}, \mathrm{NH}_{3} t} t\right)}-1}\right)-\ln \left(\frac{1}{\frac{\left[\mathrm{NH}_{3}\right]_{0}}{[\mathrm{FAC}]_{0}}-1}\right)\right)\right.}
$$

Text S7. Contributions of $\bullet \mathrm{OH}$ to observed As(III) losses during real water ozonation experiments Hydroxyl radicals $(\bullet \mathrm{OH})$ are generated continuously during real water ozonation processes, as a consequence of autocatalytic ozone decay or direct reactions between $\mathrm{O}_{3}$ and various functional moieties within dissolved organic matter $(10,11)$. Oxidation of As(III) will therefore be governed by contributions from $\mathrm{O}_{3}$ and $\bullet \mathrm{OH}$ in such systems, according to eq $\mathrm{S} 7$,

$\ln \left(\frac{[\mathrm{As}(\mathrm{III})]_{t}}{[\mathrm{As}(\mathrm{III})]_{0}}\right)=-k_{a p p, \mathrm{O}_{3}, \mathrm{As}(\mathrm{III})} \int_{0}^{t}\left[\mathrm{O}_{3}\right] d t-k_{a p p, \cdot \mathrm{OH}, \mathrm{As}(\mathrm{III})} \int_{0}^{t}[\cdot \mathrm{OH}] d t$

where $k_{\text {app, } \bullet \mathrm{OH}, \mathrm{As}(\mathrm{III})}^{\prime \prime}$ (for reaction between $\bullet \mathrm{OH}$ and $\left.\mathrm{As}(\mathrm{OH})_{3}\right)$, is $8.5( \pm 0.9) \times 10^{9} \mathrm{M}^{-1} \mathrm{~s}^{-1} \cdot \int_{0}^{t}\left[\mathrm{O}_{3}\right] d t$ can be determined by direct measurement of $\mathrm{O}_{3}(8) . \int_{0}^{t}[\bullet \mathrm{OH}] d t$ can be calculated with eq $\mathrm{S} 8(8)$,

$$
\int_{0}^{t}[\cdot \mathrm{OH}] d t=\frac{-1}{k_{a p p, \cdot \mathrm{OH}, \mathrm{P}}^{\prime \prime}} \ln \left(\frac{[\mathrm{P}]_{t}}{[\mathrm{P}]_{0}}\right)
$$

where $\mathrm{P}$ represents a probe compound that reacts selectively with $\bullet \mathrm{OH}$. $p$-Chlorobenzoic acid $(p \mathrm{CBA})$ was used as a $\bullet \mathrm{OH}$ probe in this case, because it reacts rapidly with $\bullet \mathrm{OH}\left(k_{a p p, \bullet \mathrm{OH}, p \mathrm{CBA}}^{\prime \prime}=5.0 \times 10^{9} \mathrm{M}^{-1} \mathrm{~s}^{-1}\right.$ 
(12)), and very slowly with $\mathrm{O}_{3}\left(k_{a p p, \mathrm{O}_{3}, p \mathrm{CBA}}^{\prime \prime}<0.15 \mathrm{M}^{-1} \mathrm{~s}^{-1}(13)\right)$. The relative importance of $\bullet \mathrm{OH}$ radical reactions in oxidation of As(III) during real water ozonation experiments can be expressed by eq S9,

$$
\mathrm{f}_{\cdot \mathrm{OH}, \mathrm{M}(t)}=\frac{k_{a p p, \cdot \mathrm{OH}, \mathrm{As}(\mathrm{III})} \int_{0}^{t}[\cdot \mathrm{OH}] d t}{k_{a p p, \mathrm{O}_{3}, \mathrm{As}(\mathrm{III})}^{\prime \prime} \int_{0}^{t}\left[\mathrm{O}_{3}\right] d t+k_{a p p, \cdot \mathrm{OH}, \mathrm{As}(\mathrm{III})} \int_{0}^{t}[\cdot \mathrm{OH}] d t}
$$

which represents the ratio of observed oxidation due to $\bullet \mathrm{OH}$, relative to that due to direct reactions with $\mathrm{O}_{3}$. Eq S9 was substituted with eqs S7 and S8 to yield eq S10, which was used to calculate $\mathrm{f} \cdot \mathrm{OH}, \mathrm{M}(t)$.

$$
\mathrm{f}_{\bullet \mathrm{OH}, \mathrm{M}(t)}=\frac{-\left(\frac{k_{a p p, \cdot \mathrm{OH}, \mathrm{As}(\mathrm{III})}^{\prime \prime}}{k_{a p p, \cdot \mathrm{OH}, p \mathrm{CBA}}^{\prime \prime}} \ln \left(\frac{[p \mathrm{CBA}]_{t}}{[p \mathrm{CBA}]_{0}}\right)\right)}{k_{a p p, \mathrm{O}_{3}, \mathrm{As}(\mathrm{III})}^{\prime \prime} \int_{0}^{t}\left[\mathrm{O}_{3}\right] d t-\left(\frac{k_{a p p,}^{\prime \prime} \cdot \mathrm{OH}, \mathrm{As}(\mathrm{III})}{k_{a p p}^{\prime \prime} \cdot \mathrm{OH}, p \mathrm{CBA}} \ln \left(\frac{[p \mathrm{CBA}]_{t}}{[p \mathrm{CBA}]_{0}}\right)\right)}
$$




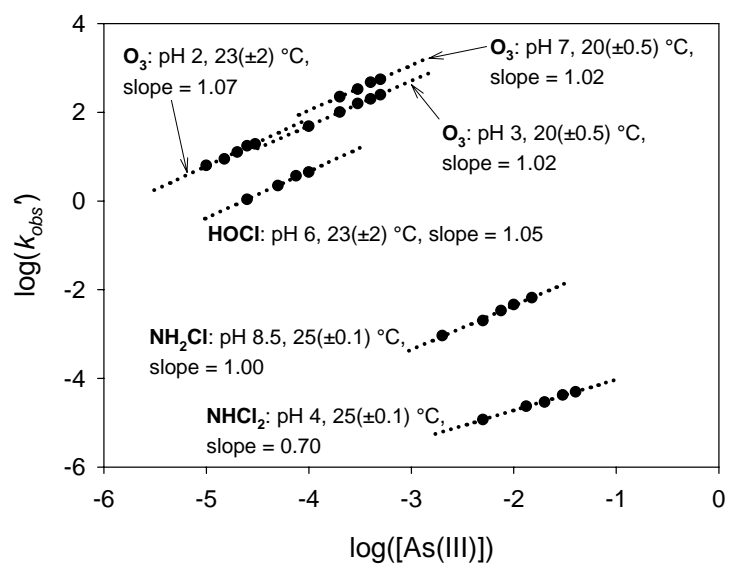

Figure S1. Reaction orders with respect to As(III) in the reactions of As(III) with $\mathrm{FAC}, \mathrm{NH}_{2} \mathrm{Cl}_{2} \mathrm{NHCl}_{2}$, and $\mathrm{O}_{3}$. $\mathrm{pH} 2 \mathrm{O}_{3}$ experiments were conducted by continuous-flow, quenched reaction monitoring. $\mathrm{pH} 3$ and $7 \mathrm{O}_{3}$ data were obtained by stopped-flow spectrophotometry.

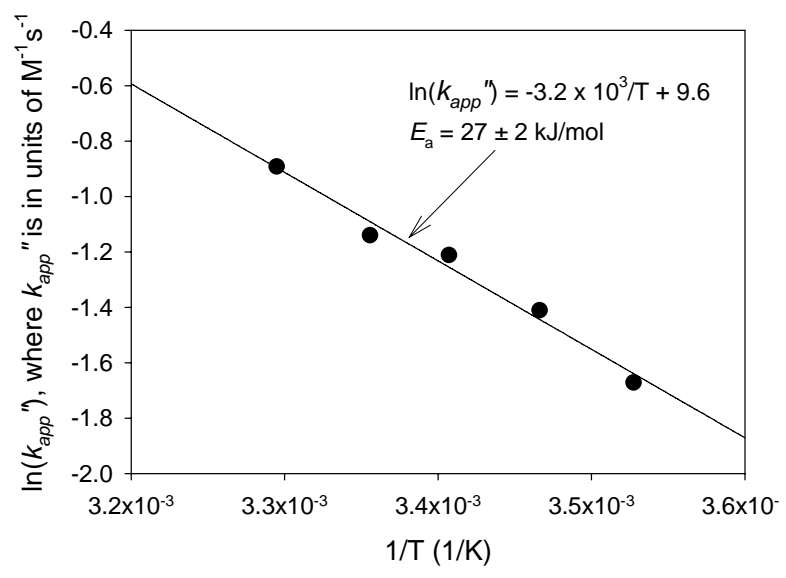

Figure S2. Temperature-dependence of apparent, second-order rate constant for decay of $\mathrm{NH}_{2} \mathrm{Cl}$ in the presence of excess As(III). Experiments conducted at $[\mathrm{As}(\mathrm{III})]=5 \times 10^{-3} \mathrm{M}$, and $\left[\mathrm{NH}_{2} \mathrm{Cl}_{0}=2 \times 10^{-4} \mathrm{M}\right.$,

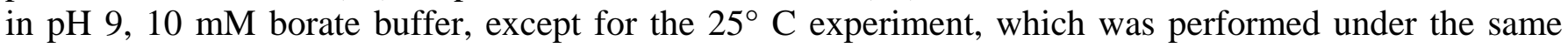
conditions in $50 \mathrm{mM}$ borate buffer. 


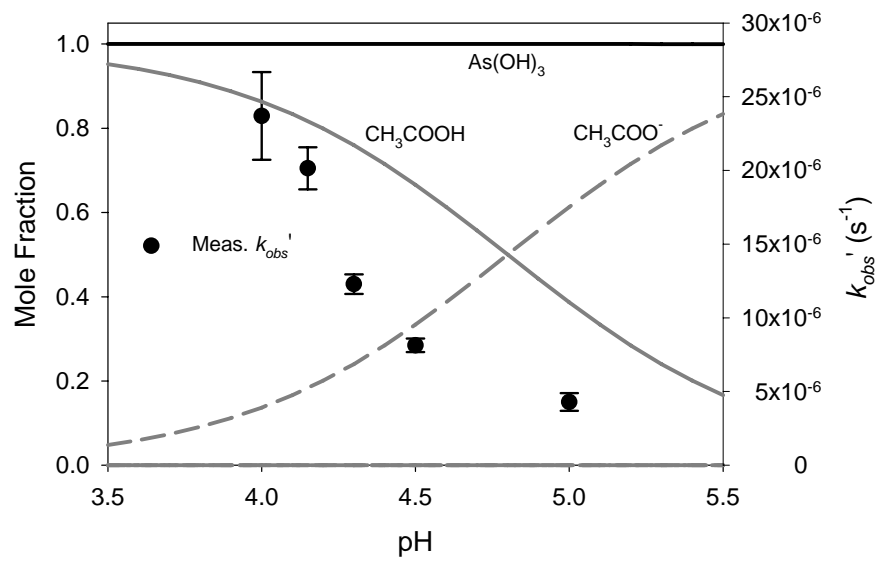

Figure S3. pH-dependence of observed pseudo-first order rate constants for decay of $\mathrm{NHCl}_{2}$ in the presence of excess As(III). Experiments conducted in $60 \mathrm{mM}$ acetate buffer, at [As(III)] $=1.3 \times 10^{-2} \mathrm{M}$, $\left[\mathrm{NHCl}_{2}\right]_{0}=3.5-5.5 \times 10^{-4} \mathrm{M}$, and $25( \pm 0.5){ }^{\circ} \mathrm{C}$. Values measured at $\mathrm{pH} 4.5$ and 5 corrected for observed losses of $\mathrm{NHCl}_{2}$ in corresponding As(III) controls.

(a)

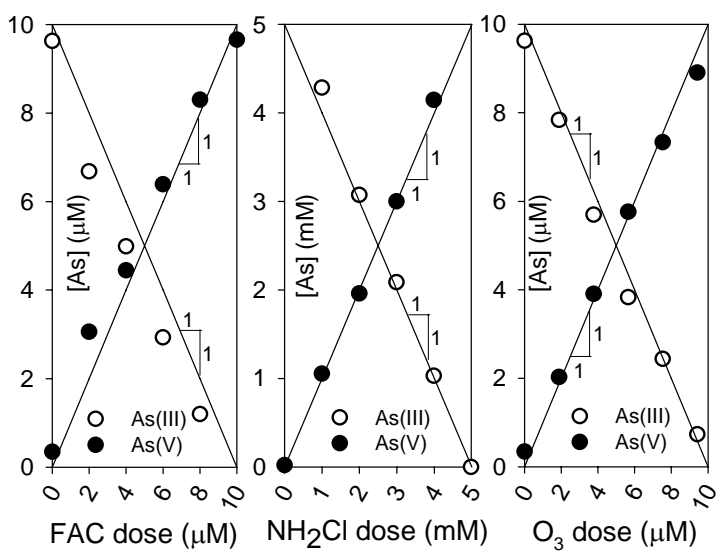

(b)

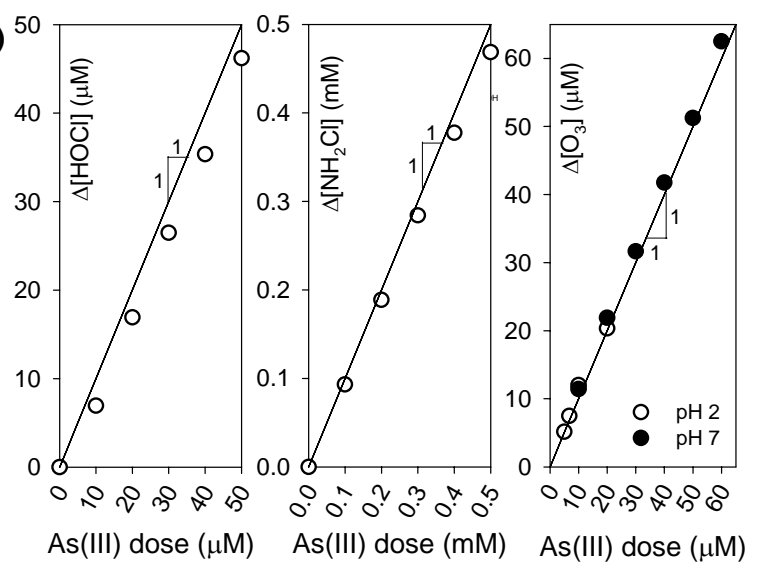

Figure S4. Observed stoichiometries for the reactions of $\mathrm{As}(\mathrm{III})$ with $\mathrm{FAC}, \mathrm{NH}_{2} \mathrm{Cl}$, and $\mathrm{O}_{3}$ : (a) $\mathrm{As}$ (III) in molar excess, and (b) oxidants in molar excess. FAC experiments conducted at $\mathrm{pH} 7, \mathrm{NH}_{2} \mathrm{Cl}$ experiments conducted at $\mathrm{pH} 9$, and $\mathrm{O}_{3}$ experiments conducted at $\mathrm{pH}$ 7. All experiments were conducted at room temperature $\left(23( \pm 2){ }^{\circ} \mathrm{C}\right)$. 


\section{Literature Cited}

1. Meng, X. G.; Wang, W. Speciation of Arsenic by Disposable Cartridges. In Book of Posters of the Third International Conference on Arsenic Exposure and Health Effects, San Diego, CA, July 1215, 1998; Society of Environmental Geochemistry and Health: University of Colorado at Denver.

2. Dodd, M.; Shah, A. D.; von Gunten, U.; Huang, C.-H., Interactions of fluoroquinolone antibacterial agents with aqueous chlorine: Reaction kinetics, mechanisms, and transformation pathways. Environ. Sci. Technol. 2005, 39, 7065-7076.

3. Standard Methods for the Examination of Water and Wastewater; 20 ed.; APHA, AWWA, WPCF: Washington, 1998.

4. Qiang, Z.; Adams, C. D., Determination of monochloramine formation rate constants with stoppedflow spectrophotometry. Environ. Sci. Technol. 2004, 38, 1435-1444.

5. Bader, H.; Hoigné, J., Determination of ozone in water by the indigo method. Water Res. 1981, 15, 449-456.

6. Staehelin, J.; Hoigné, J., Decomposition of Ozone in Water - Rate of Initiation by Hydroxide Ions and Hydrogen-Peroxide. Environmental Science \& Technology 1982, 16, 676-681.

7. $\quad$ Berg, M.; Tran, H. C.; Nguyen, T. C.; Pham, H. V.; Schertenleib, R.; Giger, W., Arsenic contamination of groundwater and drinking water in Vietnam: A human health threat. Environmental Science \& Technology 2001, 35, 2621-2626.

8. Elovitz, M. S.; von Gunten, U., Hydroxyl radical/ozone ratios during ozonation processes. I. The $\mathrm{R}_{\mathrm{ct}}$ concept. Ozone: Sci. Eng. 1999, 21, 239-260.

9. Leitzke, A.; Reisz, E.; Flyunt, R.; von Sonntag, C., The reactions of ozone with cinnamic acids: formation and decay of 2-hydroperoxy-2-hydroxyacetic acid. J. Chem. Soc., Perkin Trans. 2 2001, 793-797.

10. Buffle, M.-O.; Schumacher, J.; Salhi, E.; von Gunten, U., Measurement of the initial phase of ozone decomposition in water and wastewater by means of a continuous quench flow system: Application to disinfection and pharmaceutical oxidation. Water Research 2005, Accepted for publication.

11. von Gunten, U., Ozonation of drinking water: Part I. Oxidation kinetics and product formation. Water Res. 2003, 37, 1443-1467.

12. Neta, P.; Dorfman, L. M., Pulse radiolysis studies. XIII. Rate constants for the reaction of hydroxyl radicals with aromatic compounds in aqueous solutions. Adv. in Chem. 1968, 81, 222-230.

13. Yao, C. C. D.; Haag, W. R., Rate constants for direct reactions of ozone with several drinking water contaminants. Water Res. 1991, 25, 761-773. 